\title{
Cryptophyte bloom in a Mediterranean estuary: High abundance of Plagioselmis ef. prolonga in the Krka River estuary (eastern Adriatic Sea)
}

\author{
Luka Šupraha ${ }^{1,2}$, Sunčica Bosak ${ }^{1}$, Zrinka Ljubešić ${ }^{1}$, Hrvoje Mihanović ${ }^{3}$, Goran Olujić ${ }^{3}$, \\ Iva Mikac ${ }^{4}$, Damir Viličić ${ }^{1}$ \\ ${ }^{1}$ Department of Biology, Faculty of Science, University of Zagreb, Rooseveltov trg 6, 10000 Zagreb, Croatia. \\ ${ }^{2}$ Present address: Department of Earth Sciences, Paleobiology Programme, Uppsala University, Villavägen 16, \\ SE-752 36 Uppsala, Sweden. E-mail: luka.supraha@geo.uu.se \\ ${ }^{3}$ Hydrographic Institute of the Republic of Croatia, Zrinsko-Frankopanska 161, 21000 Split, Croatia. \\ ${ }^{4}$ Ruđer Bošković Institute, Bijenička cesta 54, 10000 Zagreb, Croatia.
}

\begin{abstract}
Summary: During the June 2010 survey of phytoplankton and physicochemical parameters in the Krka River estuary (eastern Adriatic Sea), a cryptophyte bloom was observed. High abundance of cryptophytes (maximum $7.9 \times 10^{6} \mathrm{cells}^{-1}$ ) and high concentrations of the class-specific biomarker pigment alloxanthine (maximum $2312 \mathrm{ng} \mathrm{l}^{-1}$ ) were detected in the surface layer and at the halocline in the lower reach of the estuary. Taxonomical analysis revealed that the blooming species was Plagioselmis cf. prolonga. Analysis of the environmental parameters in the estuary suggested that the bloom was supported by the slower river flow as well as the increased orthophosphate and ammonium concentrations. The first record of a cryptophyte bloom in the Krka River estuary may indicate that large-scale changes are taking place in the phytoplankton community. Such changes could have a major impact on the natural ecosystem dynamics and the mariculture production in the area.
\end{abstract}

Keywords: estuarine ecosystem; phytoplankton bloom; cryptophytes; chemotaxonomy; Mediterranean Sea; Krka River estuary.

Proliferación de una criptófita en un estuario mediterráneo: alta abundancia de Plagioselmis cf. prolonga en el estuario del río Krka (Adriático)

Resumen: Se observó una proliferación de una criptófita durante el estudio del fitoplancton y de los parámetros fisicoquímicos en el estuario del río Krka (Adriático) en junio de 2010. La abundancia más alta de criptofitas (máximo $7.9 \times 10^{6}$ células $1^{-1}$ ) y las mayores concentraciones del pigmento marcador específico de la clase, la aloxantina (máximo $2312 \mathrm{ng} \mathrm{l}^{-1}$ ), fueron detectados en la capa superficial y en la haloclina en el tramo inferior de la ría. El análisis taxonómico reveló que la especie que proliferó fue Plagioselmis cf. prolonga. El análisis de los parámetros ambientales del estuario sugirió que la proliferación estaba favorecida por el caudal lento del río, así como el aumento de las concentraciones de ortofosfato y amonio. El hecho de registrar por primera vez una proliferación de una criptófita en el estuario del río Krka podría indicar cambios a gran escala en la comunidad de fitoplancton. Tales cambios podrían tener un impacto importante en la dinámica de los ecosistemas naturales y la producción de la maricultura en la zona.

Palabras clave: estuario; proliferación de fitoplancton; criptófitas; quimiotaxonomía; mar Mediterráneo; estuario del río Krka.

Citation/Como citar este artículo: Šupraha L., Bosak S., Ljubešić Z., Mihanović H., Olujić G., Mikac I., Viličić D. 2014. Cryptophyte bloom in a Mediterranean estuary: High abundance of Plagioselmis cf. prolonga in the Krka River estuary (eastern Adriatic Sea). Sci. Mar. 78(3): 329-338. doi: http://dx.doi.org/10.3989/scimar.03998.28C

Editor: E. Garcés.

Received: December 16, 2013. Accepted: April 08, 2014. Published: July 28, 2014.

Copyright: () 2014 CSIC. This is an open-access article distributed under the Creative Commons Attribution-Non Commercial Lisence (by-nc) Spain 3.0.

\section{INTRODUCTION}

Nanoplanktonic cryptophyte flagellates (Phylum Cryptophyta, Class Cryptophyceae) are widely distributed in most aquatic habitats (Barlow and Kug- rens 2002, Barone and Naselli-Flores 2003, Novarino 2005). Current taxonomy of the group recognizes more than 200 validly described species, mostly based on light and electron microscopical observations (Cerino and Zingone 2007). Ecological investigations of cryp- 
tophytes are often hampered due to the identification issues caused by their small size (usually $<20 \mu \mathrm{m}$ ), cell fragility in common fixatives and key taxonomic characters that are difficult to observe under the light microscope. Investigations of marine cryptophyte communities with a dilution cultures method (Cerino and Zingone 2006) and molecular techniques (Metfies et al. 2010) revealed a pronounced seasonality of cryptophyte species, suggesting that the commonly used class-level approach is over-simplifying. Furthermore, species-specific aspects of cryptophyte ecology, such as mixotrophy (Tranvik et al. 1989, Roberts and Laybourn-Parry 1999), vertical migrations (Erata et al. 1995), high tolerance to environmental changes (Klaveness 1988) and interactions with other organisms such as dinoflagellates (Hackett et al. 2003, Park et al. 2006) and ciliates (Hansen and Fenchel 2006) indicate the ecological and physiological complexity of the group.

Reports of cryptophyte blooms and cryptophytedominated communities in oceanic (Gieskes and Kraay 1983, Buma et al. 1992), freshwater (Barone and Naselli-Flores 2003) and estuarine (Mallin 1994, Gameiro et al. 2004) environments show the potentially high ecological importance of cryptophytes. Furthermore, red tides caused by cryptophyte blooms were observed in natural environments (Laza-Martínez 2012 and the references therein) and enclosed oyster ponds (Pastoureaud et al. 2003). However, cryptophyte blooms in the Mediterranean Sea are very rare and exceptional events. The only reports to date were given by Andreoli et al. (1986) and Bazin et al. (2014), who investigated the red tides in the Po River delta (northern Adriatic Sea) and the Segura River estuary (western Mediterranean Sea), respectively. Cryptophytes that dominated these blooms were identified under light and electron microscope as the members of Plagioselmis (Butcher 1967), a common and widespread genus in the Mediterranean Sea (Novarino 2005).

Here we present the new report on the cryptophyte bloom in the Mediterranean Sea dominated by Plagioselmis cf. prolonga Butcher ex G. Novarino, I.A.N. Lucas and S. Morrall. The bloom is described in detail, contributing to the knowledge on the ecology and physiology of the species. Furthermore, increased cryptophyte abundance is discussed in the context of possible changes in phytoplankton communities of the Krka River estuary that might have a major impact on natural ecosystem dynamics and mariculture production in the area.

\section{MATERIALS AND METHODS}

\section{Study area}

The highly stratified Krka River estuary is situated in the central part of the eastern Adriatic Sea (Fig. 1). The estuary is $23.5 \mathrm{~km}$ long and relatively narrow except for the two larger pools, Prokljan lake and Šibenik harbour. The influence of the sea on the hydrographic properties is limited due to the low tidal range in this part of the Adriatic Sea. A sharp halocline caused by freshwater inflow is present throughout the year (Žutić and Legović 1987). The vertical gradient of salinity causes mortality and accumulation of freshwater planktonic organisms at the halocline, and the accumulated organic matter supports high bacterial production and regeneration processes (Žutić and Legović 1987, Fuks et al. 1991). The whole system is considered phosphorus-limited, except for the anthropogenicallyinfluenced Šibenik harbour pool (Legović et al. 1994). The phytoplankton community in the estuary is dominated by diatoms and the annual phytoplankton production reaches maxima in February-March and October (Viličić et al. 1989, Cetinić et al. 2006). The exceptionally large phytoplankton blooms occur either in the marine layer of the estuary or in the upstream-situated freshwater lake Visovac, and are often followed by hypoxic conditions and mass mortality of marine benthic organisms in the lower reach of the estuary (Legović et al. 1991a, Legović et al. 1991b, Petricioli et al. 1996). Owing to the favourable hydrographical parameters, the lower reach of the Krka estuary is an important area for mariculture, with the yearly production of bivalves exceeding 2000 t (Jukić et al. 2007).

\section{Sampling and measurements}

The sampling was performed in June 2010 along the lower reach of the Krka River estuary (stations E3, E4a and E5) and at the marine station (C1) near Zlarin island (Fig. 1). Six depths were sampled at each station with 5-L Niskin (Hydro-Bios, Kiel, Germany) bottle $(0.5,1.2,2,2.8,10$ and $20 \mathrm{~m}$ at E3; 0.5, 1, 1.8, 2, 10 and $30 \mathrm{~m}$ at E4a; 0.5, 1, 1.5, 4, 10 and 20 at E5; 0.5, 2, 5, 10, 20 and $25 \mathrm{~m}$ at $\mathrm{C} 1$ ). The sampling depths were selected after the examination of the temperature, salinity and chlorophyll $a$ fluorescence vertical profiles, measured using SeaBird 19 plus CTD probe (SeaBird Electronics, Inc. Washington, USA).

Standard colorimetric methods were used to determine orthophosphate (Murphy and Riley 1962), orthosilicate (Mullin and Riley 1955), nitrate, nitrite (Wood et al. 1967) and ammonium (Ivančić and Degobbis 1984) concentrations at the sampled depths.

Samples for the light microscopy (LM) analysis of phytoplankton abundance were fixed in situ in $1.4 \%$ hexamine-buffered formaldehyde (Kemika, Zagreb, Croatia) and cells were counted under the Zeiss Axiovert 200 inverted microscope (Carl Zeiss, Oberkochen, Germany) using the Utermöhl (1958) protocol. Subsamples of 10 or $50 \mathrm{ml}$ (depending on the cell density) were sedimented in Utermöhl combined plate-counting chambers (Hydro-Bios, Kiel, Germany) for $>24$ hours. Nanoplankton (cells $<20 \mu \mathrm{m}$ ) were counted at $400 \mathrm{x}$ magnification on half of the transect (i.e. 1/2 diameter of the counting chamber), and the larger cells were counted at $200 \times$ magnification (two full transects). Very abundant species were counted on a variable number (5-20) of randomly chosen fields of view at either 200 or $400 \times$ magnification depending on their size. In addition, the bottom half of the chamber was examined at a magnification of $100 \times$ to obtain a more correct evaluation of less abundant microphytoplank- 


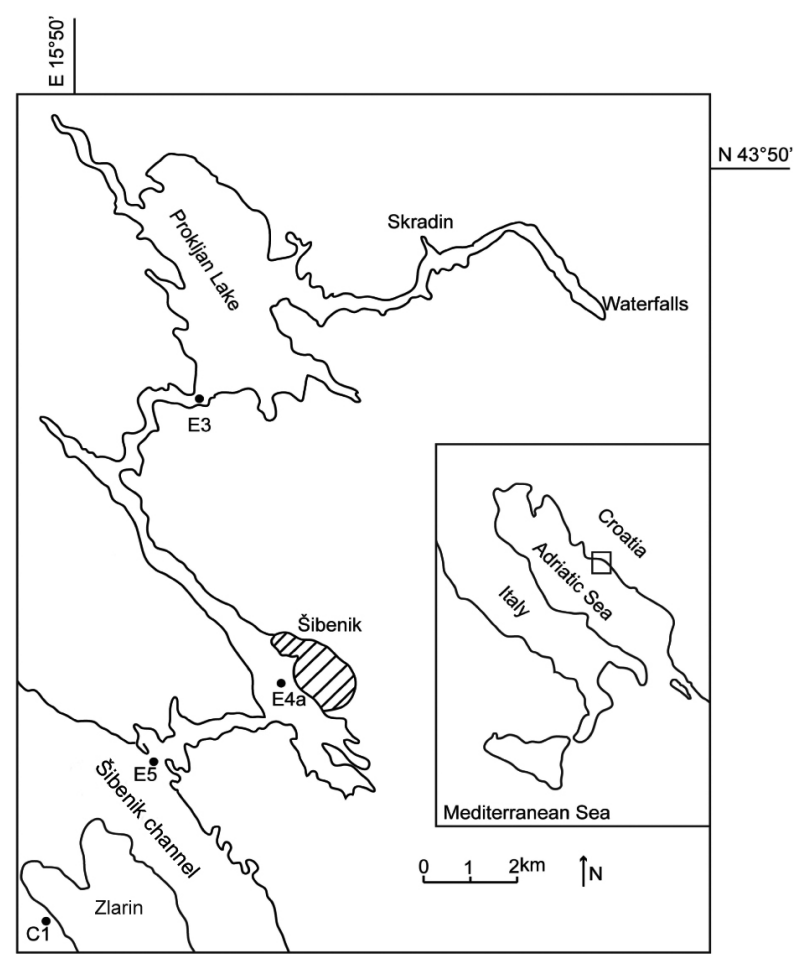

Fig. 1. - Map of the investigated area showing estuarine (E3, E4a, E5) and coastal (C1) sampling stations.

ton taxa. The minimum concentration of microphytoplankton cells that can be detected by this method is 20 cells $1^{-1}$. Cryptophyte cells were photographed under the phase contrast and differential interference contrast filters at $1000 \times$ magnification with the Zeiss MRc digital camera and analysed in Zeiss AxioVision 4.8.2. software.

For the scanning electron microscopy (SEM) analysis of field samples, $30 \mathrm{~mL}$ of $1.4 \%$ hexamine-buffered formaldehyde fixed sample from the 1-m depth of station E4a was gravity filtered on a $1-$ to $3-\mu \mathrm{m}$ pore size Nucleopore polycarbonate filter (Nucleopore, Pleasanton, CA). The filter was rinsed three times with

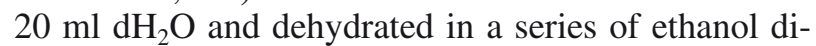
lutions $(25,35,50,75,80,90$ and $100 \%)$. After that, the filtered material was dried in a series of ethanol: hexamethyldisilazane (HMDS, Sigma-Aldrich, Seelze, Germany) dilutions (3:1, 1:1, 1:3 and 100\% HMDS). Finally, filters were air dried for 1 hour at $60^{\circ} \mathrm{C}$, sputtercoated with gold-palladium and observed using JEOL JSM-6500F (JEOL-USA Inc., Peabody, MA, USA) and Mira II FE LMU (Tescan, Brno, Chech republic) scanning electron microscopes. The cryptophyte Plagioselmis cf. prolonga was identified using the standard literature for the identification of cryptophytes (Hill 1992, Novarino et al. 1994, Novarino 2003, 2005).

Samples of 1-L volume for the high performance liquid chromatography (HPLC) analysis of phytoplankton pigments were filtered in situ on $0.7-\mu \mathrm{m}$ pore size Whatman Glass Fibre Filters (GF/F) and preserved in $-80^{\circ} \mathrm{C}$ liquid nitrogen until the analysis. The extraction in $4 \mathrm{ml}$ of cold $90 \%$ acetone was performed by sonication, and the extract was clarified by centrifugation. Pigments were separated by reversed phase
HPLC following the protocol of Barlow et al. (1997). Extracts were mixed 1:1 (v/v) with $1 \mathrm{M}$ ammonium acetate and injected into an HPLC system with the 3-mm Thermo Hypersil-Keystone column MOS2, C-8, 120 A pore size, $150 \times 4.6 \mathrm{~mm}$ (Thermo Hypersil-Keystone, Bellefonte, PA, USA). Pigments were separated at a flow rate of $1 \mathrm{~mL} \mathrm{~min}^{-1}$ using a linear gradient program with a duration of $40 \mathrm{~min}$. Solvent A consisted of 70:30 (v/v) methanol:1 M ammonium acetate and solvent B was $100 \%$ methanol. Chlorophyll and carotenoids were detected by absorbance at $440 \mathrm{~nm}$ (SpectraSYSTEM, Model UV 2000, Thermo Fischer Scientific, USA). Qualitative and quantitative analyses of individual pigments were performed by external standard calibration using authentic pigment standards (VKI, Denmark). The retention time of the cryptophyte-specific pigment alloxanthine was confirmed by the analysis of the monoculture of cryptophyte Rhinomonas cf. reticulata (Lucas) Novarino isolated from the Krka estuary.

Principal component analysis (PCA) of the environmental data with the subsequent overlay of alloxanthine concentration data was performed in Primer 6 software (Clarke and Gorley 2006). Statistica 8.0 software was used to calculate the Pearson's correlation between the alloxanthine concentration and the environmental parameters, with the significance recognized at $\mathrm{p}<0.05$. Sigma Plot 12.5 software was used for the graphical presentation of the data.

\section{RESULTS}

\section{Environmental parameters}

The sharp halocline was detected at station E3 in the 1.5- to 3-m layer and at station E4a in the 1- to 2-m layer (Fig. 2). Salinities of 32.5 to 33 were observed in the top $1.5 \mathrm{~m}$ layer at the E5 station, while the coastal marine station $\mathrm{C} 1$ had no vertical gradient of salinity. The surface temperatures ranged from 20 to $24^{\circ} \mathrm{C}$, gradually decreasing to 13 to $16^{\circ} \mathrm{C}$ in deeper layers. Minimum temperature was detected at the bottom of station $\mathrm{E} 4 \mathrm{a}\left(14.71^{\circ} \mathrm{C}\right.$ at $\left.36.2 \mathrm{~m}\right)$ while the highest temperature $\left(24.17^{\circ} \mathrm{C}\right)$ was measured in the surface layer of the same station (Table 1).

Chlorophyll $a(\mathrm{chl} a)$ concentrations at station E4a were 1484 to $5028 \mathrm{ng}^{-1}$ in the upper 2-m layer, indicating the on-going phytoplankton bloom. A strong significant correlation of alloxanthine with chl $a$ (0.968) confirmed that cryptophytes were the dominant component of the bloom. High chl $a$ values were also observed at station E3 (up to $1384 \mathrm{ng} \mathrm{l}^{-1}$ ), while the overall chl $a$ concentrations decreased downstream from station E4a, with maxima of $832 \mathrm{ng} \mathrm{l}^{-1}$ at station E5 and $276 \mathrm{ng} \mathrm{l}^{-1}$ at station $\mathrm{C} 1$. Vertical distribution of chl a at station C1 was fairly uniform, with slightly higher concentrations in the surface layer.

Concentrations of total inorganic nitrogen (TIN $=$ $\left.\mathrm{NH}_{4}^{+}+\mathrm{NO}_{2}^{2-}+\mathrm{NO}_{3}^{-}\right)$and orthosilicates decreased along the estuary, from stations E3 to E5. Concentrations were higher in the surface layer and at the halocline (Fig. 3, Table 1). The highest values of TIN and orthosilicates were detected at the halocline of station 

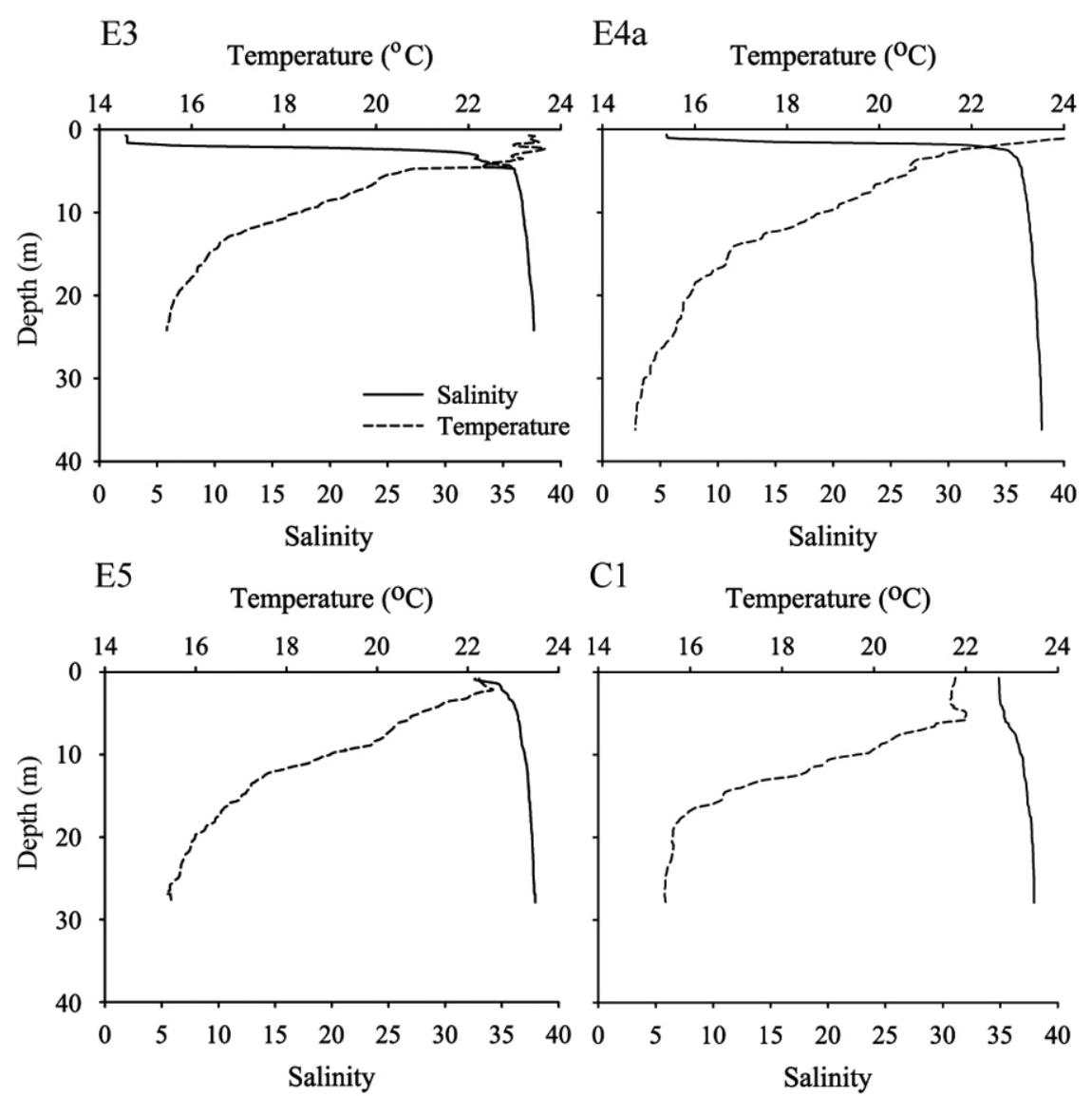

C1 Temperature $\left({ }^{\circ} \mathrm{C}\right)$

Fig. 2. - Vertical profiles of temperature (dashed line) and salinity (solid line) at the sampled stations.

E3 (13.9 and $44.1 \mu \mathrm{M} \mathrm{l}^{-1}$, respectively). The distribution of orthophosphates $\left(\mathrm{PO}_{4}{ }^{3-}\right)$ did not follow the same pattern. The highest concentration of orthophosphates was detected at the halocline of station E4a $(0.3 \mu \mathrm{M}$ $\left.1^{-1}\right)$, and the average concentrations of orthophosphates in the surface layer and the halocline of station E4a were more than three times higher than the average concentration in the area. Phosphorus limitation of the area was confirmed by the high Redfield ratio (TIN/ $\mathrm{PO}_{4}{ }^{3-}$ ), which approached values of 21.7 to 31.3 at the halocline of station $\mathrm{E} 4 \mathrm{a}$, where the $\mathrm{PO}_{4}{ }^{3-}$ concentration was the highest (Table 1). Station C1 was extremely oligotrophic, with the Redfield ratio reaching 1318 at the surface and with an average silica concentration of only $3.35 \mu \mathrm{M}^{-1}$.

\section{Plagioselmis cf. prolonga bloom}

High concentrations of alloxanthine were detected in the sub-surface layer of station E4a, with peak val- ues between 1 and 2 m depth (1434-2311 ng 1-1, Fig. 4). The abundance of cryptophytes reached maximum values at the same depth $\left(7.9 \times 10^{6}\right.$ cells $\left.1^{-1}\right)$. A high concentration of alloxanthine was also detected at station E5 at 4 m depth (240 $\left.\mathrm{ng} \mathrm{l}^{-1}\right)$, where cryptophyte abundance was $2.6 \times 10^{5}$ cells $1^{-1}$. At both E4a and E5 cryptophyte abundance was high in the surface layer and at the halocline, where cryptophytes accounted for 40 to $49 \%$ of total phytoplankton, decreasing sharply in deeper layers. A lower concentration of alloxanthine indicated a lower abundance of cryptophytes upstream from Sibenik harbour (at station E3) and at the marine station $\mathrm{C} 1$, with the contribution to total phytoplankton ranging from 2 to $15 \%$. Validity of LM counts was tested and confirmed by strong and statistically significant positive correlation of alloxanthine concentration with cryptophyte abundance (0.991).

The PCA of environmental parameters was conducted to link the distribution of alloxanthine concentrations with the physicochemical parameters. The

Table 1. - Descriptive statistics of physicochemical parameters and cryptophyte abundance. Pearson's correlation of alloxanthine concentration with the physicochemical parameters is highlighted in bold when values are statistically significant $(\mathrm{p}<0.05)$

\begin{tabular}{|c|c|c|c|c|c|c|c|c|c|c|c|}
\hline & $\begin{array}{l}\text { Temperature } \\
\left({ }^{\circ} \mathrm{C}\right)\end{array}$ & Salinity & $\begin{array}{c}\text { TIN } \\
\left(\mu \mathrm{M}^{-1}\right)\end{array}$ & $\begin{array}{c}\mathrm{NO}_{3}^{-} \\
\left(\mu \mathrm{M}^{-1}\right)\end{array}$ & $\begin{array}{c}\mathrm{NO}_{2}^{2-} \\
\left(\mu \mathrm{M}^{-1}\right)\end{array}$ & $\begin{array}{c}\mathrm{NH}_{4}^{+} \\
\left(\mu \mathrm{M}^{-1}\right)\end{array}$ & $\begin{array}{c}\mathrm{PO}_{4}^{3-} \\
\left(\mu \mathrm{M}^{-1}\right)\end{array}$ & $\begin{array}{c}\mathrm{SiO}_{4}^{4+} \\
\left(\mu \mathrm{M}^{-1}\right)\end{array}$ & $\begin{array}{c}\text { Redfield } \\
\text { ratio } \\
\left(\mathrm{TIN} / \mathrm{PO}_{4}\right)\end{array}$ & $\begin{array}{l}\text { Chlorophyll } a \\
\quad\left(\operatorname{ng~l}^{-1}\right)\end{array}$ & $\begin{array}{l}\text { Cryptophytes } \\
\quad\left(\text { cells } 1^{-1}\right)\end{array}$ \\
\hline Minimum & 14.71 & 2.29 & 1.07 & 0.18 & 0.03 & 0.86 & 0.01 & 1.86 & 21.71 & 112.61 & $8.5 \times 10^{3}$ \\
\hline Maximum & 24.17 & 37.93 & 35.04 & 11.70 & 0.37 & 2.48 & 0.30 & 44.31 & 1317.73 & 5028.75 & $7.9 \times 10^{6}$ \\
\hline Arithmetic mean & 15.69 & 29.08 & 6.61 & 2.67 & 0.14 & 1.56 & 0.07 & 15.93 & 153.33 & 1070.00 & $8.98 \times 10^{5}$ \\
\hline Standard deviation & 2.98 & 12.78 & 7.76 & 3.14 & 0.11 & 0.51 & 0.08 & 15.15 & 256.34 & 1307.88 & $2.1 \times 10^{6}$ \\
\hline Pearson's correlation & 0.395 & -0.296 & 0.242 & 0.182 & 0.557 & 0.490 & 0.950 & 0.376 & -0.218 & 0.968 & 0.991 \\
\hline
\end{tabular}



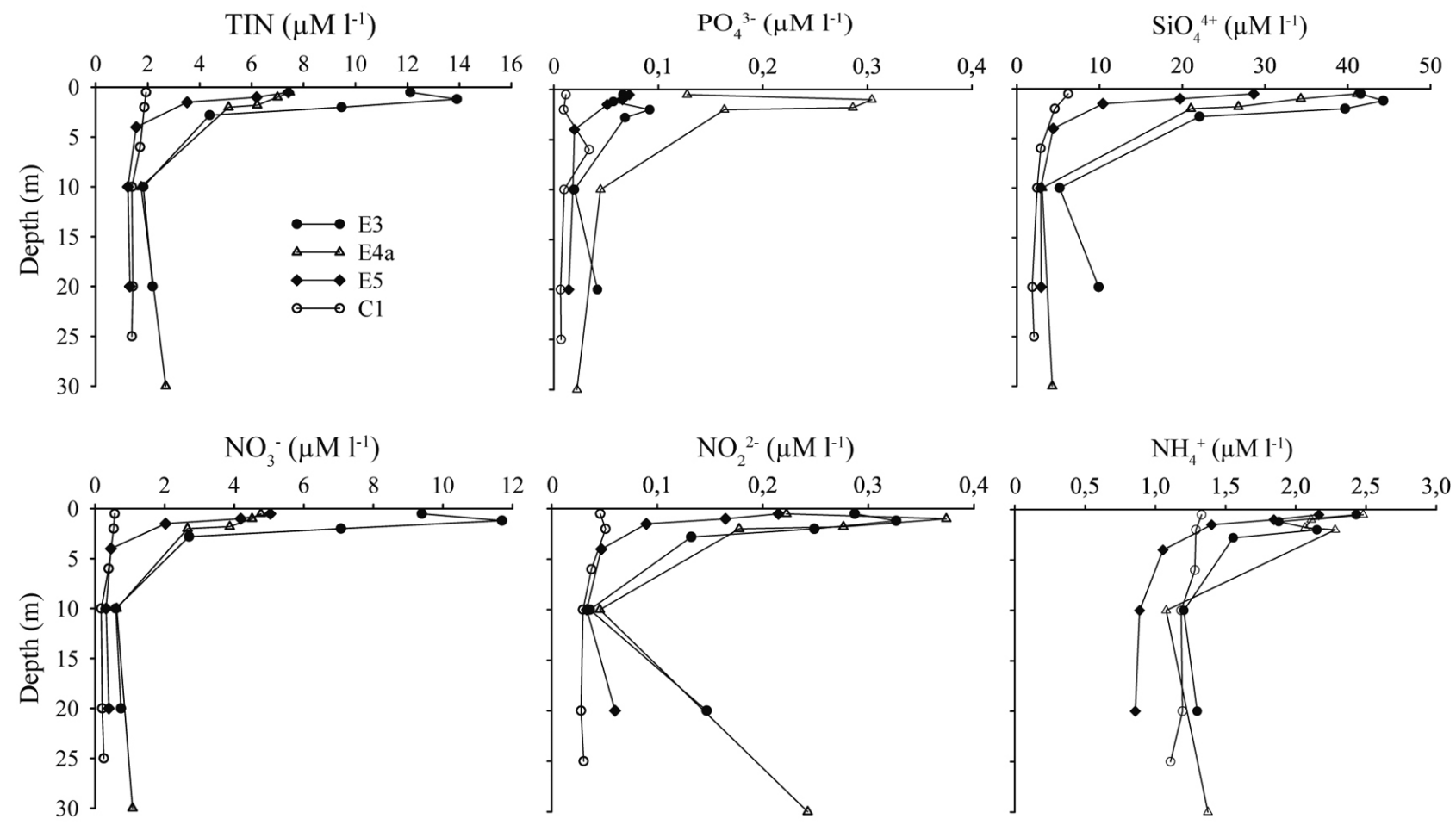

Fig. 3. - Vertical profiles of total inorganic nitrate (TIN), orthophosphate $\left(\mathrm{PO}_{4}{ }^{3-}\right)$, orthosilicate $\left(\mathrm{SiO}_{4}{ }^{4+}\right)$, nitrate $\left(\mathrm{NO}_{3}{ }^{-}\right)$, nitrite $\left(\mathrm{NO}_{2}{ }^{2-}\right)$ and ammonium $\left(\mathrm{NH}_{4}{ }^{+}\right)$concentrations at the sampled depths.

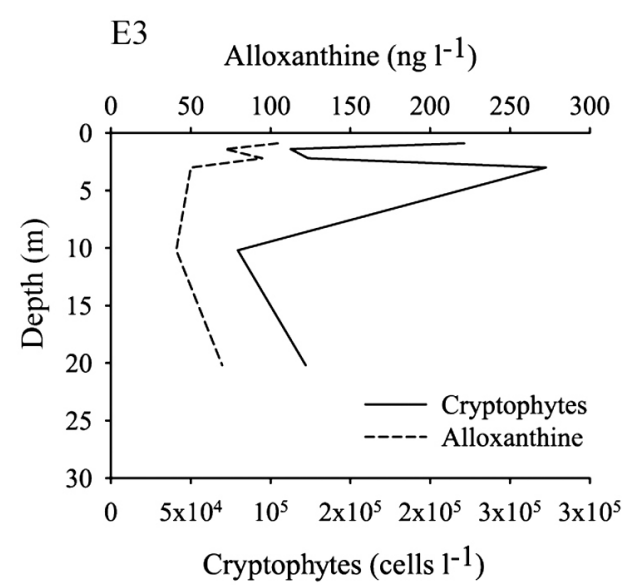

E5

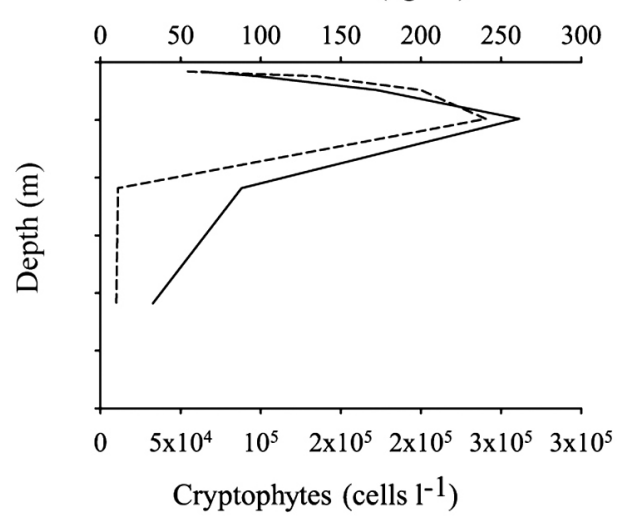

E4a Alloxanthine (ng 1-1)

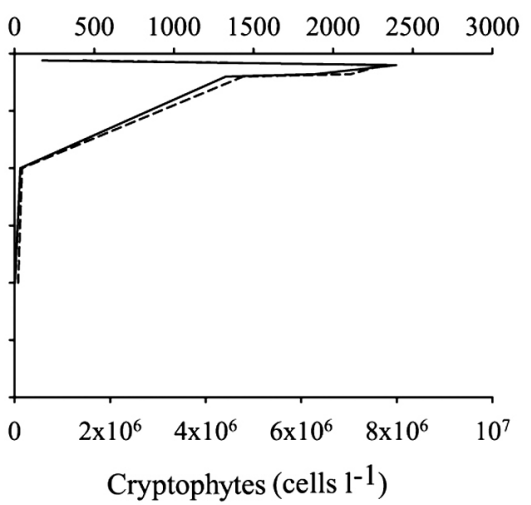

C1

Alloxanthine (ng 1 $\left.^{-1}\right)$

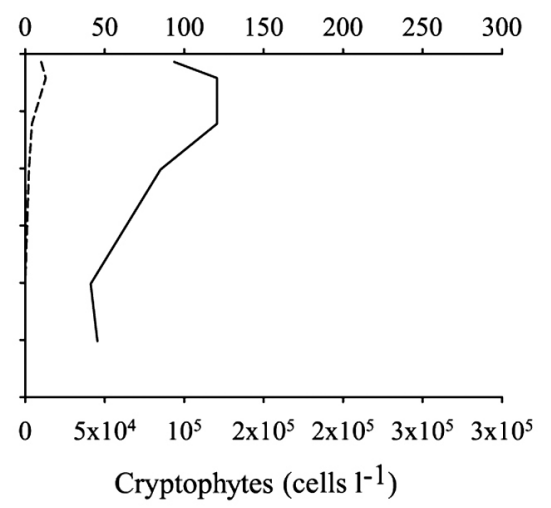

Fig. 4. - Abundance of cryptophytes determined by the LM counts (solid line) and the concentration of the class-specific pigment alloxanthine (dashed line) at the sampled depths. Note the larger scale on the graph representing station E4a. 
Table 2. - First two principal components generated by the principal component analysis of physicochemical parameters

\begin{tabular}{lcc}
\hline Variable & $\mathrm{PC} 1$ & $\mathrm{PC} 2$ \\
\hline $\mathrm{NH}_{4}{ }^{+}$ & -0.122 & -0.088 \\
$\mathrm{NO}_{2}^{2-}$ & -0.059 & -0.012 \\
$\mathrm{NO}_{3}{ }^{+}$ & -0.522 & -0.152 \\
$\mathrm{PO}_{4}{ }^{3-}$ & -0.030 & -0.041 \\
$\mathrm{SiO}_{4}{ }^{4+}$ & -0.681 & -0.476 \\
$\mathrm{Temperature}_{\text {Salinity }}$ & -0.074 & -0.053 \\
\hline
\end{tabular}

first two principal components accounted for $98 \%$ of the variance, and were both primarily defined by orthosilicates, nitrites, ammonium and salinity (Table 2). The scatter plot of the first two principal components showed three main groups of the samples (Fig. 5): A) low salinity and nutrient rich samples from the surface layer; B) intermediate salinity and nutrient-rich samples from the halocline; and C) marine samples defined by high salinity and a low nutrient concentration. An overlying plot of alloxanthine concentrations showed that cryptophytes were most abundant in the nutrientrich samples from the halocline and in the freshwater
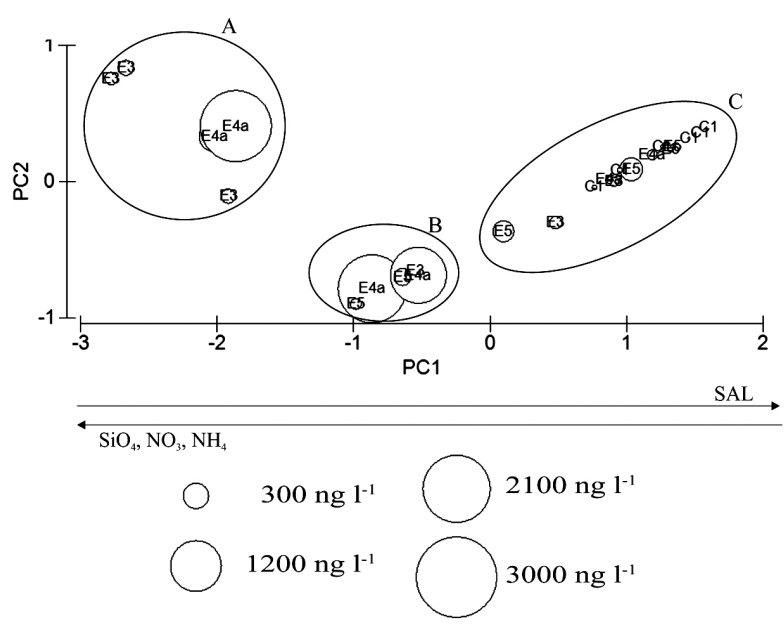

Fig. 5. - Scatterplot of the first two principal components generated by principal component analysis of physicochemical parameters. Overlaid are the alloxanthine concentration values: A, low salinity and high nutrient samples from the surface layer; B, samples from the freshwater/seawater interface (halocline); C, high salinity and low nutrient samples from deeper layers of estuarine stations and all samples from station $\mathrm{C} 1$.

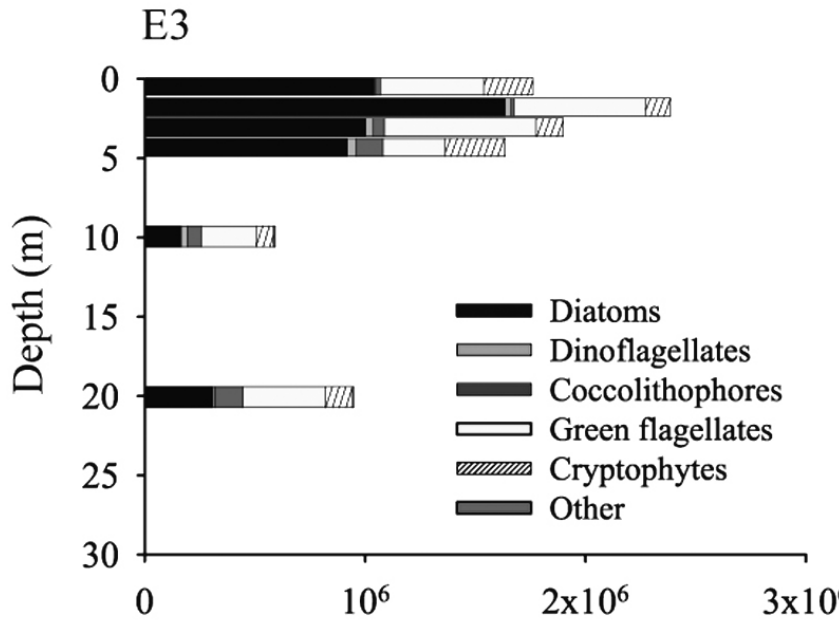

E4a

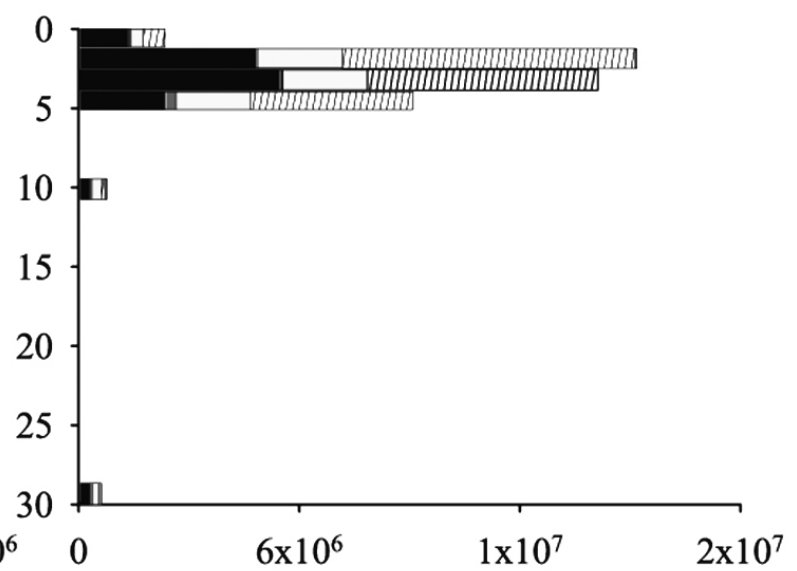

C1

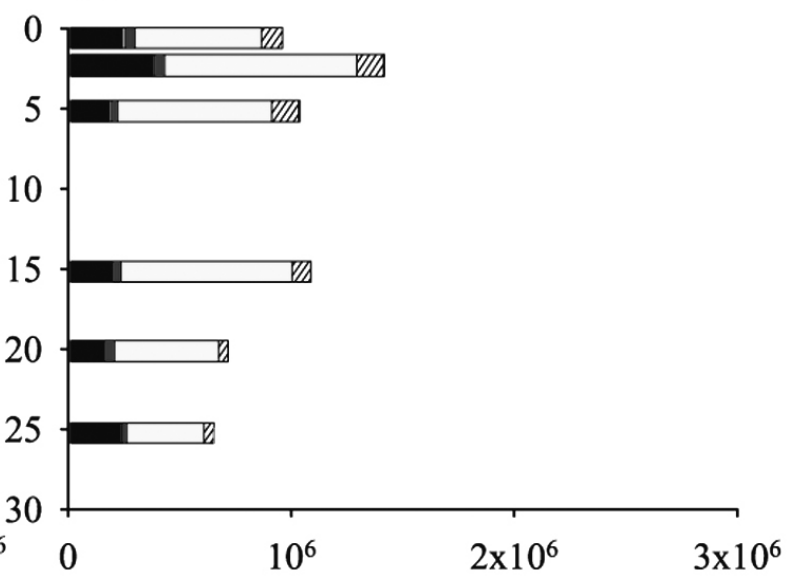

Abundance (cells 1-1)

Fig. 6. - Bar chart presentation of the abundance of main phytoplankton groups at the sampled depths. Note the larger scale on the graph presenting station $\mathrm{E} 4 \mathrm{a}$. 


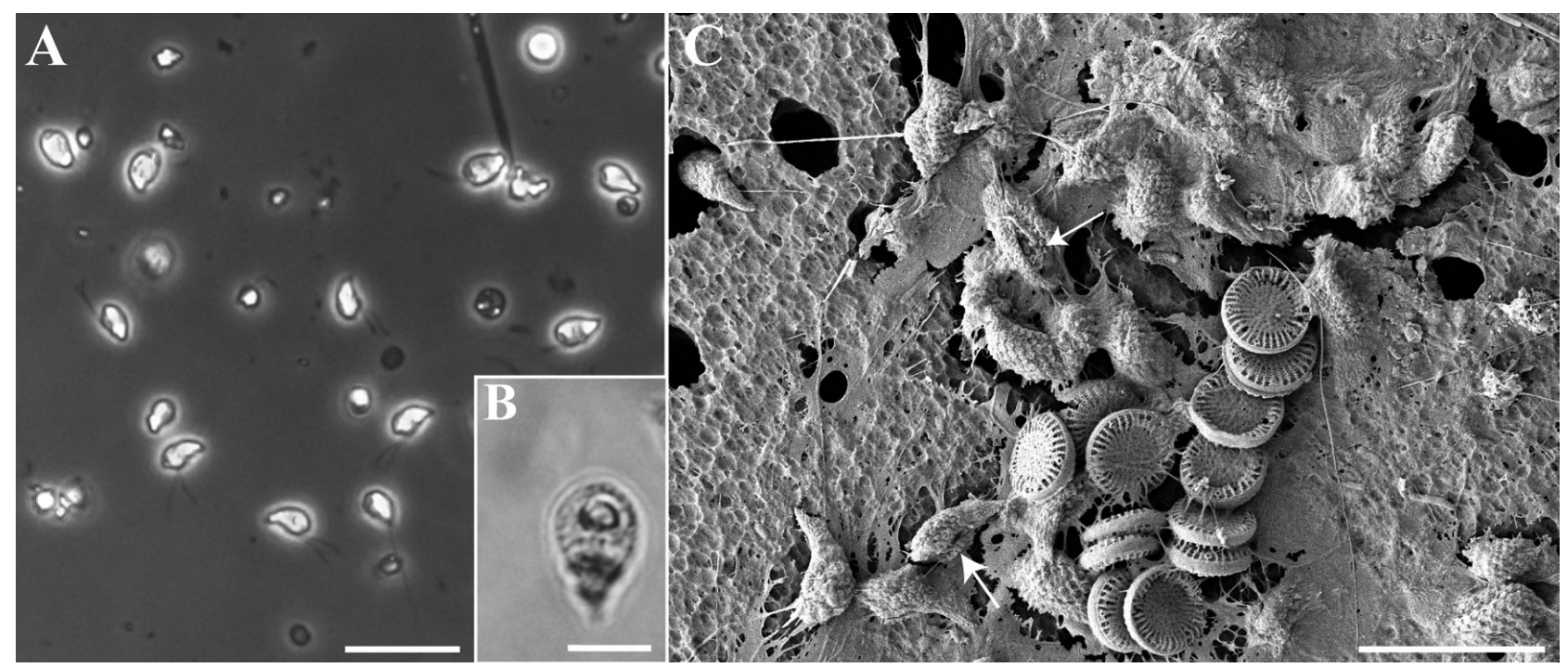

Fig. 7. - Images of Plagioselmis cf. prolonga taken with the light (A, B) and scanning electron (C) microscope. A, dominance of characteristic tear drop-like cells in the samples from station E4a (phase contrast); scale, $20 \mu \mathrm{m}$. B, cell with the centrally placed pyrenoid (differential interference contrast); scale, $10 \mu \mathrm{m}$. C, aggregates containing Plagioselmis cf. prolonga and nanoplanktonic centric diatoms. Hexagonal plates are visible on all cells. Furrow is visible on cells that are lying on dorsal side (arrows); scale, $10 \mu \mathrm{m}$.

layer. At the time of the bloom, cryptophytes were present at very low salinity values $(2.5$ and 5.5 at the surface layer of stations E3 and E4a, respectively), which indicates their high tolerance to decreased salinity. Furthermore, alloxanthine concentration showed a significant positive correlation with phosphates (0.950), ammonium (0.490) and nitrite (0.557) (Table 1).

Along with cryptophytes, the samples were rich in green flagellates, the most abundant group at station $\mathrm{C} 1$ (maximum $8.6 \times 10^{5}$ cells $\mathrm{l}^{-1}$ at $2 \mathrm{~m}$ depth) and co-dominant at station $\mathrm{E} 4 \mathrm{a}$, and in diatoms, which dominated stations E3 and E5, and were very abundant $\left(5.4 \times 10^{6}\right.$ cells $\mathrm{l}^{-1}$ ) below the halocline of station E4a (Fig. 6). The diatom assemblage at all stations was dominated by marine nanoplanktonic single-celled Chaetoceros species ( $C$. subtilis, $C$. throndsenii and $C$. tenuissimus) and small colonial centric diatoms belonging to the $C y$ clotella genus. The freshwater layer and the halocline at the estuarine stations were also abundant in terms of the large freshwater diatom Synedra acus. A very low abundance of dinoflagellates, coccolithophores and other groups was observed throughout the estuary.

Cryptophytes were identified at the class level during LM counts, and no quantitative taxonomic composition was determined. However, most of the cells counted throughout the estuary represented a distinct morphotype (Fig. 7A). The LM and SEM analysis of field samples revealed that the blooming cryptophyte belonged to the genus Plagioselmis. Cells were teardrop-shaped, 6-10 $\mu \mathrm{m}$ long and 4-6 $\mu \mathrm{m}$ wide, with two long flagella (Fig. 7A, B). Under the LM, the large central pyrenoid was visible (Fig. 7B). Due to the formaldehyde fixation, cells lost their characteristic redbrownish colour and chloroplasts were poorly visible. Hexagonal plates were clearly visible under the SEM (Fig. 7C). A prominent furrow, extending up to $2 / 3$ of the cell length from the anterior to the posterior end was also observed (Fig. 7C). Cells were often associated with large amounts of sticky mucous matter that was visible under both LM and SEM, forming aggregates that contained cells of other phytoplankton (Fig. 7C). Taxonomical analysis using the available taxonomic literature (Hill 1992, Novarino et al. 1994, Novarino 2003, 2005) suggested that the blooming species was Plagioselmis cf. prolonga Butcher ex G. Novarino, I.A.N. Lucas and S. Morrall.

\section{DISCUSSION}

Although the riverine inflow determined the depth of the halocline, vertical distribution of temperature was regulated by the solar radiation. Distribution of orthosilicates was defined by the river inflow, while high concentrations of TIN and orthophosphates at station E4a (Šibenik harbour) probably originated from both anthropogenic input and microbial regeneration. Nutrient enrichment, slower river flow and the increased temperature supported the cryptophytedominated bloom.

Novarino (2005) hypothesized that Plagioselmis prolonga is the key primary producer in the pelagic ecosystems of the Mediterranean Sea. The association of the species with sticky organic exopolymers presented in his study was also observed during the bloom of Plagioselmis cf. prolonga in the Krka estuary. It is not clear whether the organic exopolymers were excreted naturally by Plagioselmis cf. prolonga or the cells were attracted to the organic exopolymers excreted by other phytoplankton cells. Since all Plagioselmis species are free-swimming and do not excrete organic exopolymers in culture (Novarino et al. 1994), observed exopolymers may also be a fixation artefact such as discharged ejectisomes (Booth et al. 1982). The species blooming in the Krka estuary was highly tolerant of low salinity. Similar euryhaline characteristics were reported for other cryptophyte species that form blooms in estuarine ecosystems (Mallin 1994, Gameiro et al. 2004, Laza-Martínez 2012). 
Cryptophyte blooms are rarely reported in marine and estuarine phytoplankton communities of the Mediterranean Sea. As a result, detailed ecological data linked with particular species are scarce. Furthermore, a high degree of species-specific and strain-specific seasonality in cryptophytes further complicates research on their ecological preferences and possible triggers of blooms. Available reports on the ecology of Plagioselmis spp. shed more light on the ecological preferences of the genus. Cerino and Zingone (2006) found that the species Plagioselmis prolonga is present throughout the year in Mediterranean coastal waters, and the peak abundance $\left(6.8 \times 10^{5}\right.$ cells $\left.1^{-1}\right)$ was detected in April. The bloom of Plagioselmis sp. detected by Andreoli et al. (1986), and probably misidentified as Chroomonas sp. (Novarino 2005) in the eutrophic Po River delta reached an abundance of $50 \times 10^{6}$ cells $1^{-1}$. The bloom reported by Andreoli et al. was detected in winter, and characterized by discolouration in form of a red tide. Such discolouration was not detected in our study, possibly due to the almost seven times lower abundance of cryptophytes during the bloom in the Krka estuary. The green discolouration observed in the Krka estuary was probably caused by the other groups (e.g. green flagellates) in the surface layer, while cryptophytes dominated at the halocline. Another bloom of the cryptophyte identified as Plagioselmis prolonga was recently given by Bazin et al. (2014). The bloom was detected in the early spring at the halocline of the Segura River estuary, with cell counts reaching $156 \times 10^{6}$ cells $1^{-1}$. High phosphate concentrations (up to $6 \mu \mathrm{M} \mathrm{1}^{-1}$ ) and stratification of the water column contributed to bloom development. The blooms of Plagioselmis spp. were also observed outside the Mediterranean Sea, as reported by Seoane et al. (2012) in bays and estuaries of the Cantabrian coast (Bay of Biscay, Spain). Seasonal differences between reported blooms of Plagioselmis spp. detected in the same water body (Mediterranean Sea) and at a similar latitude indicate that the genus comprises a high diversity of physiologically and ecologically different strains and species.

Statistical analysis suggests that the cryptophyte bloom at station E4a was linked to the higher concentration of orthophosphates at the halocline. The main sources of orthophosphates in Šibenik harbour are anthropogenic eutrophication and bacterial regeneration of the organic matter (Fuks et al. 1991, Legović et al. 1994). Orthophosphate concentration in this oligotrophic estuary was high enough to trigger the bloom, and low enough to favour the growth of small-sized phytoplankton taxa (nanoplanktonic diatoms, cryptophytes and green flagellates).

Investigations conducted in other anthropogenically-influenced estuaries have detected a shift in the dominant communities due to increased levels of ammonium. High concentrations of ammonium (usually higher than $4 \mu \mathrm{M}^{-1}$ ) inhibit the uptake of nitrate, thus limiting the growth of larger diatoms and favouring smaller primary producers such as cryptophytes and green flagellates (Dugdale et al. 2012). The concentrations of ammonium during our study were highest (2.8 $\left.\mu \mathrm{M}^{-1}\right)$ at the depths where cryptophytes bloomed, and showed a significant positive correlation with the alloxanthine. It could be hypothesized that ammonium was the primary nitrogen source at station E4a, suggesting much higher initial concentration before the bloom that could have been limiting for larger diatoms.

Previous investigations of the phytoplankton in the Krka estuary (Cetinić et al. 2006, Svensen et al. 2007) reported that diatoms dominate the summer phytoplankton community, with peak abundances upstream from Sibenik harbour. The shift from diatom-dominated summer blooms in the upper reach of the estuary (station E3) to the cryptophyte-dominated blooms in the anthropogenically-influenced Šibenik harbour (station E4a) observed in our work supports our hypothesis that the phytoplankton community is undergoing changes due to eutrophication.

High abundance of cryptophytes may affect the mariculture production. Although cryptophytes are considered a "high-quality" food, lacking hard exoskeleton structures or toxic metabolic products (Brett and Müller-Navarra 1997, Sterner and Schulz 1998), their higher content in bivalve food causes the red colouration of the tissue, making the mariculture products unfavourable for commercial needs (Pastoureaud et al. 2003). Furthermore, cryptophytes are essential for the development of toxic or harmful blooms of some dinoflagellates (Adolf et al. 2008) and ciliates (Peterson et al. 2013). Such diverse interactions of cryptophytes with their environment and their importance for the marine food web emphasize the necessity for future monitoring of phytoplankton communities and environmental parameters in the area in order to detect the changes that might have a profound effect on the estuary's ecosystem dynamics and mariculture production.

\section{ACKNOWLEDGEMENTS}

The field work was supported by the Croatian Ministry of Science, Education and Sports through the project 119-1191189-1228. We would like to thank Professor Marijan Ahel from the Ruđer Bošković Institute in Zagreb for providing HPLC instrumentation. We are grateful to Dario Omanović, Zdeslav Zovko and Zvonko Roman from the same institution for their help during the field sampling. We would also like to thank Illiam Jackson from Uppsala University for valuable comments on the English language.

\section{REFERENCES}

Adolf J.E., Bachvaroff T., Place A.R. 2008. Can cryptophyte abundance trigger toxic Karlodinium veneficum blooms in eutrophic estuaries? Harmful Algae 8(1): 119-128. http://dx.doi.org/10.1016/j.hal.2008.08.003

Andreoli C., Tolomio C., Rascio N., et al. 1986. Some observations on a cryptophycea responsible for a winter red bloom. G. Bot. Ital. 120: 70-71.

Barlow R.G., Mantoura R.F.C., Cummings D.G., et al. 1997. Pigment chemotaxonomic distributions of phytoplankton during summer in the western Mediterranean. Deep Sea Res. II Top. Stud. Oceanogr. 44(3-4): 833-850.

Barlow S. B., Kugrens P. 2002. Cryptomonads from the Salton Sea, California. Hydrobiologia 473(1-3): 129-137. http://dx.doi.org/10.1023/A:1016585818665

Barone R., Naselli-Flores L. 2003. Distribution and seasonal dy- 
namics of Cryptomonads in Sicilian water bodies. Hydrobiologia 502: 325-329.

http://dx.doi.org/10.1023/B:HYDR.0000004290.22289.c2

Bazin P., Jouenne F., Deton-Cabanillas A.-F., et al. 2014. Complex patterns in phytoplankton and microeukaryote diversity along the estuarine continuum. Hydrobiologia 726(1): 155-178. http://dx.doi.org/10.1007/s10750-013-1761-9

Booth B.C., Lewin J., Norris R.E. 1982. Nanoplankton species predominant in the subarctic Pacific in May and June 1978. Deep Sea Res. Part A. Oceanogr. Res. Pap. 29(2): 185-200. http://dx.doi.org/10.1016/0198-0149(82)90108-X

Brett M., Müller-Navarra D. 1997. The role of highly unsaturated fatty acids in aquatic foodweb processes. Freshwat. Biol. 38(3): 483-499. http://dx.doi.org/10.1046/j.1365-2427.1997.00220.x

Buma A.G.J., Gieskes W.W.C., Thomses H.A. 1992. Abundance of Cryptophyceae and chlorophyll b-containing organisms in the Weddell-Scotia confluence area in the spring 1988. Polar Biol. 12: 43-52. http://dx.doi.org/10.1007/BF00239964

Butcher R.W. 1967. An introductory account of the smaller algae of British coastal waters. Part IV: Cryptophyceae. Fish. Invest. London Ser. 4: 1-54.

Cerino F., Zingone A. 2006. A survey of cryptomonad diversity and seasonality at a coastal Mediterranean site. Eur. J. Phycol. 41: 363-378.

http://dx.doi.org/10.1080/09670260600839450

Cerino F., Zingone A. 2007. Decrypting cryptomonads: a challenge for molecular taxonomy. In: Brodie J., Lewis J. (eds), Unravelling the algae: the past, present, and future of algal systematics. The Systematics Association Special Volume Series, pp. 197-214. http://dx.doi.org/10.1201/9780849379901.ch11

Cetinić I., Viličić D., Burić Z., et al. 2006. Phytoplankton seasonality in a highly stratified karstic estuary (Krka, Adriatic Sea). Hydrobiologia 555(1-2): 31-40. http://dx.doi.org/10.1007/s10750-005-1103-7

Clarke K.R., Gorley R.N. 2006. PRIMER v6: User manual/tutorial. PRIMER-E. Plymouth.

Dugdale R., Wilkerson F., Parker A.E., et al. 2012. River flow and ammonium discharge determine spring phytoplankton blooms in an urbanized estuary. Estuar. Coast. Shelf Sci. 115(0): 187-199.

http://dx.doi.org/10.1016/j.ecss.2012.08.025

Erata M., Kubota M., Takahashi T., et al. 1995. Ultrastructure and phototactic action spectra of two genera of cryptophyte flagellate algae, Cryptomonas and Chroomonas. Protoplasma 188: 258-266. http://dx.doi.org/10.1007/BF01280378

Fuks D., Devescovi M., Precali R., et al. 1991. Bacterial abundance and activity in the highly stratified estuary of the Krka River. Mar. Chem. 32: 333-346. http://dx.doi.org/10.1016/0304-4203(91)90047-Z

Gameiro C., Cartaxana P., Cabrita M.T., et al. 2004. Variability in chlorophyll and phytoplankton composition in an estuarine system. Hydrobiologia 525: 113-124. http://dx.doi.org/10.1023/B:HYDR.0000038858.29164.31

Gieskes W.W.C., Kraay G.W. 1983. Dominance of Cryptophyceae during the phytoplankton spring bloom in the central North Sea detected by HPLC analysis of pigments. Mar. Biol. 75: 179-185. http://dx.doi.org/10.1007/BF00406000

Hackett J.D., Maranda L., Su Yoon H., et al. 2003. Phylogenetic evidence for the cryptophyte origin of the plastid of Dinophysis (Dinophysiales, Dinophyceae). J. Phycol. 39: 440-448. http://dx.doi.org/10.1046/j.1529-8817.2003.02100.x

Hansen P.J., Fenchel T. 2006. The bloom-forming ciliate Mesodinium rubrum harbours a single permanent endosymbiont. Mar. Biol. Res. 2: 169-177. http://dx.doi.org/10.1080/17451000600719577

Hill D.R.A. 1992. Plagioselmis prolonga Butcher (Cryptophyceae). Baltic Sea Phytoplankton identification Sheet No. 8. Ann. Bot. Fenn. 29: 165-166.

Ivančić I., Degobbis D. 1984. An optimal manual procedure for ammonia analysis in natural waters by the indophenol blue method. Water Res. 18(9): 1143-1147. http://dx.doi.org/10.1016/0043-1354(84)90230-6

Jukić D., Carević T., Švonja M. 2007. Prijedlog plana upravljanja slivnim područjem rijeke Krke (Proposal for river basin water management plan for the river Krka). In: Gereš D. (ed.) 4. hrvatska konferencija o vodama, Hrvatske vode i Europska unija- izazovi i mogućnosti. University Library, Zagreb, Opatija, Croatia, pp. 931-936.

Klaveness D. 1988. Ecology of the Cryptomonadida: A First Review. In: Sandgren C.D. (ed). Growth and reproductive strategies of freshwater phytoplankton. Cambridge University Press, pp. $105-133$

Laza-Martínez A. 2012. Urgorri complanatus gen. et sp. nov. (Cryptophyceae), a red-tide-forming species in brackish waters. J. Phycol. 48 (2): 423-435. http://dx.doi.org/10.1111/j.1529-8817.2012.01130.x

Legović T., Petricioli D., Žutić V. 1991a. Hypoxia in a pristine stratified estuary (Krka, Adriatic Sea). Mar. Chem. 32: 347-360. http://dx.doi.org/10.1016/0304-4203(91)90048-2

Legović T., Viličić D., Petricioli D., et al. 1991b. Subsurface Gonyaulax polyedra bloom in a stratified estuary. Mar. Chem. 32 361-374. http://dx.doi.org/10.1016/0304-4203(91)90049-3

Legović T., Žutić V., Gržetić Z., et al. 1994. Eutrophication in the Krka estuary. Mar. Chem. 46(1-2): 203-215. http://dx.doi.org/10.1016/0304-4203(94)90056-6

Mallin M. 1994. Phytoplankton ecology of North Carolina estuaries. Estuaries 17(3): 561-574. http://dx.doi.org/10.2307/1352404

Metfies K., Gescher C., Frickenhaus S., et al. 2010. Contribution of the Class Cryptophyceae to phytoplankton structure in the German Bight. J. Phycol. 46(6): 1152-1160. http://dx.doi.org/10.1111/j.1529-8817.2010.00902.x

Mullin J.B., Riley J.P. 1955. The colorimetric determination of silicate with special reference to sea and natural waters. Anal. Chim. Acta 12(0): 162-176. http://dx.doi.org/10.1016/S0003-2670(00)87825-3

Murphy J., Riley J.P. 1962. A modified single solution method for the determination of phosphate in natural waters. Anal. Chim. Acta 27: 31-36. http://dx.doi.org/10.1016/S0003-2670(00)88444-5

Novarino G. 2003. A companion to the identification of cryptomonad flagellates (Cryptophyceae $=$ Cryptomonadea). Hydrobiologia 502: 225-270. http://dx.doi.org/10.1023/B:HYDR.0000004284.12535.25

Novarino G. 2005. Nanoplankton protists from the western Mediterranean Sea. II. Cryptomonads (Cryptophyceae = Cryptomonadea). Sci. Mar. 69: 47-74. http://dx.doi.org/10.3989/scimar.2005.69n147

Novarino G., Lucas I.A.N., Morrall S. 1994. Observations on the genus Plagioselmis (Cryptophyceae). Cryptogamie Algol. 15: 87-107.

Park M.G., Kim S., Kim H.S., et al. 2006. First successful culture of the marine dinoflagellate Dinophysis acuminata. Aquat. Microb. Ecol. 45: 101-106. http://dx.doi.org/10.3354/ame045101

Pastoureaud A., Dupuy C., Chrétiennot-Dinet M.J., et al. 2003. Red coloration of oysters along the French Atlantic coast during the 1998 winter season: implication of nanoplanktonic cryptophytes. Aquaculture 228(1-4): 225-235. http://dx.doi.org/10.1016/S0044-8486(03)00266-7

Peterson T.D., Golda R.L., Garcia M.L., et al. 2013. Associations between Mesodinium rubrum and cryptophyte algae in the Columbia River estuary. Aquat. Microb. Ecol. 68(2): 117-130. http://dx.doi.org/10.3354/ame01598

Petricioli D., Bakran-Petricioli T., Viličič D., et al. 1996. Freshwater Phytoplankton Bloom in Visovac Lake - A Possible Cause of Benthic Mortality in Krka Estuary (Adriatic Sea, Croatia). Mar. Ecol. 17(1-3): 373-382 http://dx.doi.org/10.1111/j.1439-0485.1996.tb00515.x

Roberts E. C., Laybourn-Parry J. 1999. Mixotrophic cryptophytes and their predators in the Dry Valley lakes of Antarctica. Freshwat. Biol. 41: 737-746. http://dx.doi.org/10.1046/j.1365-2427.1999.00401.x

Seoane S., Puente A., Guinda X., et al. 2012. Bloom forming and toxic phytoplankton in transitional and coastal waters of Cantabria region coast (Southeastern Bay of Biscay, Spain). Mar. Pollut. Bull. 64(12): 2860-2866. http://dx.doi.org/10.1016/j.marpolbul.2012.08.023

Sterner R., Schulz K. 1998. Zooplankton nutrition: recent progress and a reality check. Aquat. Ecol. 32 (4): 261-279. http://dx.doi.org/10.1023/A:1009949400573

Svensen C., Viličić D., Wassmann P., et al. 2007. Plankton distribution and vertical flux of biogenic matter during high summer stratification in the Krka estuary (Eastern Adriatic). Estuar. Coast. Shelf Sci. 71: 381-390. 
$338 \cdot$ L. Šupraha et al.

http://dx.doi.org/10.1016/j.ecss.2006.07.022

Tranvik L., Porter K., Sieburth J. 1989. Occurrence of bacterivory in Cryptomonas, a common freshwater phytoplankter. Oecologia 78(4): 473-476.

http.//dx doi.oro/10.1007/BF00378736

Utermöhl H. 1958. Zur Vervollkommnung der quantitativen Phytoplankton-Methodik. Mitt. int. Ver. Limnol. 9: 1-38.

Viličić D.. Legović T., Žutić V. 1989. Vertical distribution of phytoplankton in a stratified estuary. Aquat. Sci. 51(1): 31-46.

http://dx.doi.org/10.1007/BF00877779
Wood E., Armstrong F., Richards F. 1967. Determination of nitrate in sea water by cadmium-copper reduction to nitrite. J. Mar. Biol. Assoc. U.K. 47(1): 23-31.

http://dx.doi.org/10.1017/S002531540003352X

Žutić V., Legović T. 1987. A film of organic matter at the freshwater/sea-water interface of an estuary. Nature 328(6131): 612-614.

http://dx.doi.org/10.1038/328612a0 